\title{
METODE PENGATURAN PENGGUNAAN TENAGA LISTRIK DALAM UPAYA PENGHEMATAN BAHAN BAKAR PEMBANGKIT DAN ENERGI
}

\author{
Oleh : Widodo *)
}

\begin{abstract}
Abstrak
Dalam pengoperasian sisitem tenaga listrik harus selalu diusahakan agar daya yang dibangkitkan sama dengan permintaan daya system. Pengaturan pembangkitan untuk memenuhi permintaan tenaga listrik, disusun menurut prioritas, yaitu pembangkit dengan biaya bahan bakar paling murah ditempatkan untuk mendukung beban dasar, sedangkan pembangkit yang tidak efektif digunakan untuk mendukung waktu beban puncak.
\end{abstract}

Pengaturan penggunaan tenaga listrik adalah program pengaturan waktu dan besaran pemakaian tenaga listrik agar diperoleh pemakaian yang efisien dan hemat. Pengaturan dilakukan dengan menurunkan atau menghemat tenaga listrik, pemasangan beban puncak dan pengalihan beban dari waktu beban puncak (WBP) ke luar waktu beban puncak (LWBP), sehingga suplai pembangkit yang tidak efisien bahan bakarnya dapat berkurang. Metoda pengaturan pemakaian tenaga listrik dari sisi pengguna adalah high efficiency lighting, improved refrigerators, improved air conditioning, improved motors, penggunaan tenaga listrik pada luar waktu beban puncak, energy manajement audits, efficient new construction. Pelaksanaan metoda tersebut perlu penghematan sosialisasi ke konsumen tenaga listrik. Penghematan yang diperoleh dapat digunakan untuk menunda rencana pembangunan system tenaga listrikyang disebabkan pertumbuhan permintaan tenaga listrik, pemenuhan permintaan calon pelanggan tenaga listrik dan menurunkan pembayaran rekening listrik.

Kata Kunci : Metode Pengaturan, Pemakaian Listrik, Efisiensi

\section{PENDAHULUAN}

Menurut jenis arusnya, system tenaga listrik dikenal dengan system arus bolakbalik (AC) dan system arus searah (DC). Pada system $A C$, penaikkan dan penurunan tegangan, medan magnet putarnya mudah dilakukan. Maka berdasarkan kemudahan tersebut, hampir di seluruh dunia menggunakan system tenaga listrik $A C$, Walaupun system DC juga mulai dikembangkan dengan pertimbanganpertimbangan tertentu. Sementara sisitem AC tidak dapat disimpan, sehingga dalam memenuhi permintan konsumen, pusat listrik harus dioperasikan sesuai denga permintaan konsumen yang berubah dari waktu ke waktu.

Sistem tenaga listrik dibangkitkan dalam pusat-pusat listrik dan disalurkan ke konsumen melalui jaringan saluran tenaga listrik. Mesin-mesin pembangkit pada pusatpusat listrik, menggunakan bahan bakar yang berbeda-beda dengan kapasitas yang berlainan pula. Sehingga dalam pengoperasian mesin pembangkit perlu direncanakan seoptimal mungkin agar diperoleh biaya bahan bakar yang hemat namun mutu dan keandalan tetap terjaga.
Listrik merupakan bentuk energy yang paling cocok dan nyaman bagi manusia modern. Makin bertambahnya konsumsi listrik per kapita diseluruh dunia menunjukkan kenaikan standar kehidupan manusia. Dengan pertumbuhan permintaan tenaga listrik, maka harus direncanakan pembangunan pusat-pusat listrik baru, atau menciptakan bentuk-bentuk energy baru untuk mendukungnya; apabila kapasitas pusat listrik yang ada pada saat ini tidak cukup mendukungnya. Pembangunan tenaga listrik memerlukan dana yang besar dan waktu yang lama, selain juga pertimbangan-pertimbangan politis, ketersediaan bahan bakar dan sumber daya manusianya.

Untuk dapat dicapai tujuan yang seimbang antara pemenuhan kebutuhan pada saat sekarang maupun pertumbuhan permintaan tenaga listrik dan penyediaan, dilakukan penghematan baik dari sisi penyedia listrik maupun dari sisi pengguna tenaga listrik. Metoda penghematan dan pengaturan pnyediaan tenaga listrik dibahas dalam tulisan ini.

\footnotetext{
*) Dosen Teknik Elektro

Universitas PGRI Adi Buana Surabaya
} 


\section{PROSES PENYAMPAIAN TENAGA LISTRIK}

Karena berbagai persoalan teknis, tenaga listrik hanya dibangkitkan pada tempat-tempat tertentu saja. Sedangkan pemakai tenaga listrik atau pelanggan tenaga listrik tersebar diberbagai tempat, maka penyampaian tenaga listrik dari tempat dibangkitkan sampai ke tempat pelanggan memerlukan berbagai penanganan teknis. Tenaga listrik dibangkitkan dalam Pusatpusat listrik seperti PLTA, PLTU, PLTG, PLTP, PLTGU dan PLTD, kemudian disalurkan melalui saluran transmisi setelah terlebih dahulu dinaikkan tegangan oleh transformator penaik tegangan yang ada dipusat listrik. Saluran tegangan tinggi di Indonesia mempunyai tegangan $150 \mathrm{kV}$ yang disebut sebagai Saluran Udara Tegangan Tinggi (SUTT) dan tegangan 500 kV yang disebut sebagau Saluran Udara Tegangan Ekstra Tinggi (SUTET). Saluran transmisi ada yang berupa saluran udara dan ada pula yang berupa kabel tanah. Karena saluran udara harganya jauh lebih murah dibandingkan dengan kabel tanah, maka saluran transmisi kebanyakan berupa saluran udara. Kerugian saluran transmisi menggunaka kabel udara adalah adanyta gangguan petir, kena pohon dan lain-lain.

Setelah tenaga listrik disalurkan melalui saluran transmisi, maka sampailah tenaga listrik di Gardu Induk (Gl) untuk diturunkan tegangannya melalui transformator penurun tegangan menjadi tegangan menengah atau yang disebut juga tegangan distribusi primer. Tegangan distribusi primer yang digunakan saat ini adalah tegangan $20 \mathrm{kV}$. Jaringan setelah keluar dari Gl disebut jaringan distribusi, sedangkan jaringan antara pusat listrik dengan Gl disebut jaringat transmisi. Setelah tenaga listrik disalurkan melalui jaringan distribusi primer, maka kemudian tenaga listrik diturunkan tegangannya dalam gardu gardu distribusi menjadi tegangan rendah dengan tegangan 380/2220 Volt, kemudian disalurkan melalui jaringan tegangan rendah. Dalam praktek karena luasnya jaringan distribusi, sehingga diperlukan banyak transformator distribusi, maka Gardu distribusi seringkali disederhanakan menjadi transformator tiang. Pelanggan yang mempunyai daya sambung besar tidak dapat disambung melalui jaringan tegangan rendah, melainkan disambung langsung pada jaringan tegangan tegangna menengah, bahkan ada pula yang disambung pada jaringan transmisi tegangan tinggi, tergantung besarnya daya sambung.

Setelah tenaga listrik melalui jaringan tegangan menengah (JTM), jaringan tegangan rendah (JTR) dan sambungan rumah, maka tenaga listrik selanjutnya melalui alat pembatas daya dan KWH meter. Dari uraian tersebut, dapat dimengerti bahwa besar kecilnya konsumsi tenaga listrik ditentukan sepenuhnya oleh para pelangga akan menggunakan alat-alat listriknya, yang harus diikuti besarnya suplai tenaga listrik dari pusat-pusat listrik. Proses penyampaian tenaga listrik dari pusat-pusat listrik ditunjukkan dalam gambar 1 .

\section{PEMAKAIAN TENAGA LISTRIK}

Pemakaian tenaga listrik oleh konsumen berubah-ubah setiap waktu, maka pusat-pusat listrik membangkitkan daya sesuai dengan permintaan yang berubahubah tersebut. Perubahan beban dan perubahan pembangkitan daya juga menyebabkana aliran daya dalam saluransaluran transmisi berubah-ubah sepanjang waktu. Apabila daya nyata yang dibangkitkan oleh pusat-pusat listrik lebih kecil daripada daya yang dibutuhkan oleh para pelanggan, maka frekuensi akan turun, sebaliknya apabila lebih besar, frekuensi akan naik. Pusat listrik berkewajiban menyediakan tenaga listrik yang frekuensinya tidak menyimpang dari 50 Hertz.

Penyediaan tenaga listrik diupayakan dengan biaya serendah mungkin dengan tetap menjaga mutu dan keandalan. Dalam proses penyediaan tenaga listrik tidak dapat dihindarkan timbulnya rugi-rugi dalam jaringan disamping adanya tenaga listrik yang harus disisihkan untuk pemakaian sendiri.Proses pembangkitan tenaga listrik dalam pusat-pusat listrik thermos memerlukan biaya bahan bakar yang lebih mahal daripada pusat-pusat listrik dengan menggunakan tenaga air. Biaya bahan bakar serta rugi-rugi dalam jaringan merupakan factor-faktor yang harus ditekan agar menjadi sekecil mungkin dengan tetap memperhatikan mutu dan keandalan.

Mutu dan keandalan tenaga listrik tidak semata-mata merupakan masalah operasi system tenaga listrik, tetapi erat kaitannya denga pemeliharaan instalasi tenaga listrik dan juga erat kaitannya dengan 
masalah pengembangan system tenaga listrik, mengingat bahwa konsumsi tenaga listrik oleh pelanggan selalu bertambah dari waktu ke waktu. Oleh karena hasil-hasil operasi system tenaga listrik perlu dianalisa dan dievaluasi untuk menjadi masukan dalam perencanaan pengembangan tenaga listrik. Mutu tenaga listrik yang baik merupakan kendala (counstrain) terhadap biaya pelanggan tenga listrik yang serendah mungkin, maka kompromi antara kedua hal ini perlu direncanakan dengan optimal. Salah satu data operasi sistem tenaga listrik adalah kecenderungan pemakaian tenaga listrik konsumen dari menit ke menit yang dituangkan dalam bentuk kurva, digunakan untuk menentukan kesiapan pusat-pusat listrik beroperasi mensuplai tenaga listrik kedalam sistem. Contoh kurva pemakaian tenaga listrik oleh konsumen ditunjukkan dalam Gambar 2 dan gambar 3.

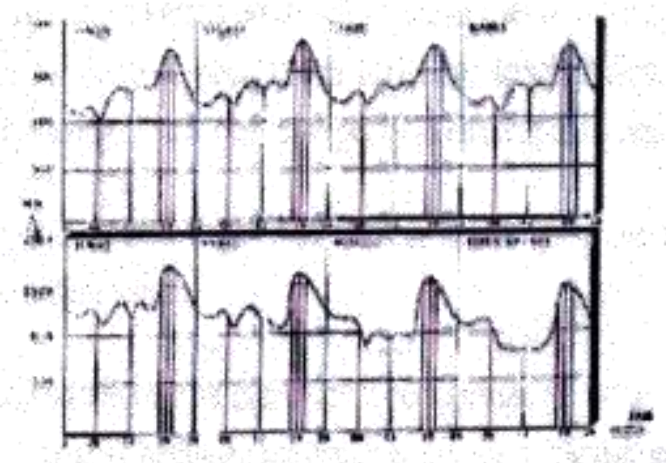

Gambar 2. Kurva Pemakaian Listrik Konsumen dalam 1 Minggu

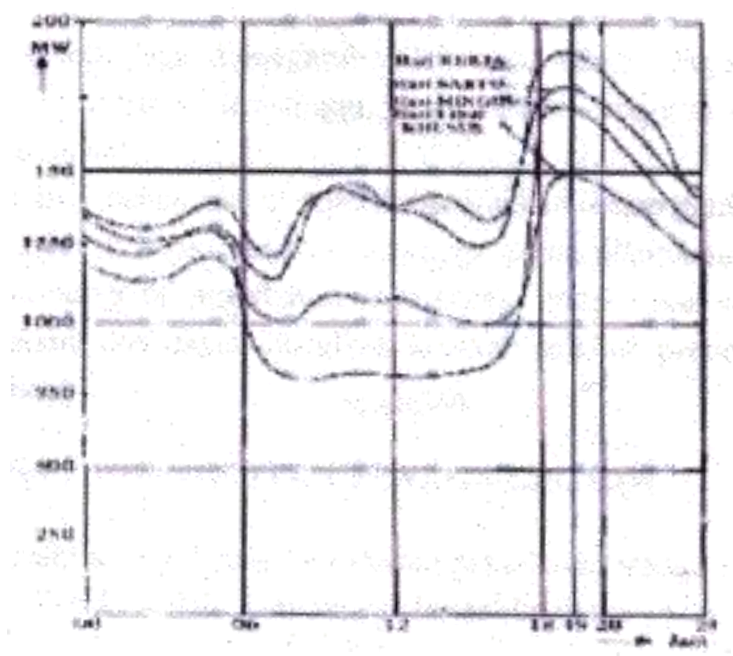

Gambar 3. Kurva Pemakaian Listrik Konsumen Perhari
Dari gambar 2 dan 3 dapat diambil kesimpulan mengenai beban sisitem sebagai berikut :

1. Beban puncak selalu terjadi di sekitar jam 19.00, yaitu pada malam hari. Ini berarti bahwa pemakaian tenaga listrik untuk keperluan penerangan masih lebih banyak dibandingkan pemakaian tenaga listrik untuk keperluan industri.

2. Pada pagi hari sekitar jam 05.00 selalu ada kenaikkan beban sebentar yang kemudian diikutu dengan penurunan beban pada sekitar jam 06.00 pagi. Hal ini disebabkan karena sekitar jam 05.00 pagi para pemakai tenaga listrik telah bangun, menyalakan lampu untuk sembahyang dan melakukan persiapanpersiapan untuk bekerja. Setelah matahari terbit, kira-kira jam 06.00, lampu-lampu dimatikan dan beban turun.

3. Beban terndah terjadi untuk setiap antara jam 06.00 dan jam 07.30 karena pada saat ini lampu-lampu sudah dimatikan tetapi belum ada kegiatan yang menambah pemakaian listrik dalam masyarakat.

4. Untuk hari minggu dan hari libur saat terjadinya beban terendah ini lebih siang, lebih kekanan seperti tampak pada gambar 3 , disebabkan karena kegiatan masyarakat yng memerlukan tambahan tenaga listrik terjadi lebih siang pada hari minggu dan libur dibandingkan pada hari-hari kerja. Untuk hari senin seperti ditunjukkan pada gambar 2, Nampak bahwa nilai beban terendah ini adalah paling rendah dibandingkan hari-hari kerja lainnya, hal ini mungkin disebabkan karena masih adanya pengaruh week end terhadap kegiatan pemakaian tenaga listrik oleh masyarakat.

5. Beban hari sabtu untuk setiap jam yang sama adalah lebih rendah daripada untuk hari kerja lainnya. $\mathrm{Hal}$ ini disebabkan karena adanya perusahaanperusahaan yang tidak bekerja pada hari sabtu.

6. Beban hari minggu untuk setiap jam yang sama adalah lebih rendah daripada beban hari kerja (termasuk hari sabtu), hal ini disebabkan karena sebagian besar perusahaan tidak bekerja pada hari minggu.

7. Beban hari libur khusus seperti hari raya Idul fitri dan Tahun Baru untuk jam yang sama adala lebih rendah daripada 
beban hari minggu. Hal ini disebabkan karena tidak adanya siaran televise di sinag hari Libur dan juga oleh karena pada kedua hari libur tersebut diatas kegiatan pemakaian tenaga listrik oleh para pemakai adalah paling rendah.

8. Dari pengamatan operasi dapat disampaikan hal-hal yang mempengaruhi beban harian sistem yaitu :

a. Beban sistem banyak dipengaruhi penggunaan peralatan informatik yang menarik perhatian masyarakat, misalnya televise, internet dan lain-lain.

b. Beban sistem juga dipengaruhi oleh suhu udara, dimana makin tinggi suhu udara makin tinggi beban sistem yang konsumsi oleh penyejuk udara.

c. Karakteristik beban sistem seperti ditunjukkan dalam gambar, perlu diamati secara terus menerus, sehingga dapat dilakukan berbagai evaluasi mengenai masalah operasi sistem untuk masa-masa yang akan datang dan dapat diusulkan langkah-langkah preventif yang perlu diambil.

\section{PENGATURAN PEMBANGKITAN TENAGA LISTRIK}

Beban sistem tenaga listrik merupakan pemakaian tenaga listrik dari para pelanggan listrik. Oleh karenanya besar kecilnya beban beserta perubahannya tergantung kepada kebutuhan para pelanggan akan tenaga listrik. Dalam pengoperasian sistem tenaga listrik harus selalu diusahakan agar daya yang dibangkitkan sama dengan beban sistem. Maka setelah diketahui kecenderungan pemakaian tenaga listrik seperti ditunjukkan dalam gambar 2 dan 3, disusun unit-unit pembangkit yang harus melayani permintaan beban.

Pengaturan pembangkitan pada umumnya didasarkan pada biaya bahan bakar per kilowattjam yang digunakan oleh mesin pembangkit energy listrik, sebab biaya bahan bakar merupakan biaya terbesar dalam pembangkitan energy listrik. Oleh karenanya diperlukan suatu cara untuk menghitung biaya bahan bakar yang diperlukan dalam pengoperasian sistem tenaga listrik untuk kurun waktu tertentu. Untuk dapat menentukan susunan pengoperasian pembangkit, kurva beban harian seperti ditunjukkan dalam gambar 2 dan 3 diubah menjadi kurva lama beban yang menunjukkan hubungan kemampuan mensuplai daya (watt) dengan lama waktu kemampuan melayani (tahun). Unit-unit pembangkit diurut menurut urutan prioritas mulai dari yang termurah biaya bahan bakarnya, dipartisipasikan dalam memenuhi beban sistem. Misalkan beban dasar segmen OABC (Unit 1) didukung oleh PLTA, segmen ADEB (Unit 2) didukung oleh PLTU Batubara, segmen DGFE (Unit 3) PLTU Gas, dan segmen terakhir (Unit 4) didukung PLTP dan pembangkit kecilkecil dengan bahan bakar minyak yang lebih mahal per kWhnya, seperti pembangkit listrik diesel.

\section{PENGATURAN PEMAKAIAN TENAGA LISTRIK}

Pengaturan pemakaian energy listrik pada dasarnya adalah suatu kegiatan masyarakat pelanggan listrik untuk mengubah perilaku agar menggunakan tenaga listrik secara efisien, baik besaran maupun waktunya, sehingga dapat memberikan manfaat bagi pelanggan itu sendiri, perusahaan listrik, maupun masyarakat pengguna tenaga listrik pada umumnya.

\section{a. Manfaat Pengaturan pemakaian energy listrik bagi perusahaan listrik adalah :}

1. Dapat mengurangi biaya bahan bakar, biaya operasi dan biaya pemeliharaan.

2. Dapat menunda pembangunan pembangkit listrik dan jaringan listrik dalam rangka memenuhi pertumbuhan permintaan tenaga listrik.

3. Dapat tetap menjaga ketersediaan pasokan tenaga listrik, karena kapasitas yang mampu melayani permintaan tenaga listrik dapat dihemat.

b. Manfaat pengaturan pemakaian energy listrik bagi pengguna tenaga listrik adalah :

1. Dapat menghindari pemadaman bergilir yang dikarenakan ketidak mampuan pusat listrik untuk mensuplai tenaga listrik sesuai permintaan. Hal ini terjadi pada saat permintaan tenaga listrik secara 
bersamaan pada waktu beban puncak.

2. Dapat menghemat sumber daya alam, dimana bahan bakar yang diproduksi dari alam dan tidak dapat diperbarui dapat dihemat.

3. Dapat memberikan kesempatan penyediaan tenaga listrik bagi masyarakat yang belum menikmati tenaga listrik. Sebab dengan pengurangan pemakaian tenaga listrik, berarti ada sisa kapasitas tersedia yang dapat disalurkan ke masyarakat yang belum menikmati tenaga listrik.

\section{c. Sasaran pengaturan pemakaian} energy listrik adalah :

1. Konservasi energy, adalah program untuk menurunkan/menghemat pemakaian tenaga listrik.

2. Pemasangan beban puncak, adalah program untuk mengurangi beban pada waktu beban puncak. Hal ini pada umunya dilakukan untuk memperbaiki sistem pasokan/penyaluran tenaga listrik dengan pemadaman atau pengurangan beban untuk pengguna tenaga listrik bukan industry.

3. Pengalihan beban, adalah program untuk menggeser beban dari waktu beban puncak (WBP) ke luar waktu beban puncak (LWBP), sehingga diperoleh pembebanan pada saat LWBP meningkat. Dengan demikian akan diperoleh penghematan pemakaian bahan bakar, karena pendukung beban dasar adalah pembangkit yang menggunakan bahan bakar lebih murah.

\section{METODA PENGATURAN PEMAKAIAN TENAGA LISTRIK}

\section{a. Efisiensi penerangan}

1. Gunakan lampu hemat energy

2. Menghidupkan lampu hanya pada saat diperlukan saja

3. Mewarnai dinding, lantai dan langit-langit dengan warna terang, sehingga tidak membutuhkan penerangan yang berlebihan.

4. Memasang lampu penerangan dalam jarak yang tepat dengan obyek yang akan diterangi
5. Mengatur perlengkapan rumah agar tidak menghalangi penerangan.

\section{b. Lemari pendingin}

1. Memilih lemari es denga ukuran/kasitas yang sesuai.

2. Membuka pintu lemari es seperlunya, dan pada kondisi tertentu agar dapat tertutup rapat.

3. Mengisi lemari es secukupnya (tidak melebihi kapasitas).

4. Menempatkan lemari es jauh dari sumber panas, seperti sinar matahari, kompor.

5. Meletakkan lemari es minimal $15 \mathrm{~cm}$ dari dinding/tembok rumah.

6. Tidak memasukkan makanan/minuman yang masih panas ke dalam lemari es.

7. Membersihkan kondensor (terletak di belakang lemari es) secara teratur dari debu dan kotoran, agar proses pelepasan panas berjalan baik.

8. Mengatur suhu lemari es sesuai dengan kebutuhan karena semakin rendah/dingin temperatur, semakin banyak konsumsi energy lisrrik.

9. Mematikan lemari es bila tidak digunakan dalam waktu lama.

c. Pengatur suhu udara (AC)

1. Memilih $A C$ hemat energy dan daya yang sesuai dengan besarnya ruangan.

2. Mematikan AC bila ruangan tidak digunakan.

3. Mengatur suhu ruangan secukupnya, tidak menyetel AC terlalu dingin.

4. Menutup pintu, jendela dan ventilasi ruangan agar udara panas dari luar tidak masuk.

5. Menempatkan AC sejauh mungkin dari sinar matahari langsung agar efek pendingin tidak berkurang.

6. Membersihkan saringan (filter) udara dengan teratur.

d. Motor-motor

1. Memilih motor sesuai dengan kegunaan dan kapasitas.

2. Menentukan seting tegangan yang tidak berlebihan. Untuk 
motor dengan range tegangan $380 \mathrm{~V}$ sampai $400 \mathrm{~V}$, sebaiknya di set pada tegangan $380-385$ V.

3. Memilih motor-motor yang mampu mengontrol penyerapan daya listrik sesuai dengan beban. Motor elevator dengan muatan 9 orang, dipilih yang mampu menyerap daya kurang dari spesifikasi maksimum apabila penumpang kurang dari 9 orang.

4. Melakukan pemeriksaan terjadwal agar motor berfungsi sesuai dengan spesifikasinya.

e. Pemakaian tenaga listrik pada beban puncak

Penyerapan daya listrik jika memungkinkan disebar pada waktu beban puncak, sehingga mengurangi pengoperasian pembangkit yang tidak efisien.

\section{f. Audit Energi}

Menghitung besarnya konsumsi energy listrik pada bangunan gedung dan mengenali cara-cara untuk penghematannya. g. Konstruksi bangunan yang efisien Dalam rekayasa bangunan gedung diupayakan semaksimal mungkin agar efisiensi penerangan, efisiensi pengaturan suhu udara, pengaturan instalasi listrik, dapat dimaksimalkan. Motor-motor produksi sedapat mungkin dekat dengan pusat listrik (transformator).

\section{KESIMPULAN}

Pelaksanaan metoda tersebut perlu dilakukan sosialisasi ke konsumen tenaga listrik, dan diharapkan dengan pengaturan penggunaan tenaga listrik, membuat masyarakat pengguna tenaga listrik makin mengetahui pentingnya tenaga listrik. Penghematan yang diperoleh dapat digunakan untuk menunda rencana pembangunan sistem tenaga listrik yang disebabkan pertumbuhan permintaan tenaga listrik, pemenuhan permintaan calon pelanggan tenaga listrik dan menurunkan pembayaran rekening listrik.

\section{DAFTAR PUSTAKA}

Amirullah M, MA'. Tarif Listrik yang mengacu pada efisiensi Sumber Daya Nasional serta Metodologi Peramalan Kebutuhan Listrik. PT PLN (Persero). Jakarta, 1993

Annonymus. Penyusunan Prakiraan Kebutuhan Listrik. Dinas Penelitian Kebutuhan Listrik. PT.PLN (Persero). Jakarta, 1996

Annonymus. Long-range Energy Alternatives Lpanning System. Stockholm Environment Institude, Boston USA, 2000.

Annonymus. Rencana Umum Ketenagalistrikan nasional. Keputusan Menteri Energi dan Sumber Daya Mineral nomer : 0954/K/30/MEM/2004. Jakarta, 2000 